\author{
BULETINUL INSTITUTULUI POLITEHNIC DIN IAŞI \\ Publicat de \\ Universitatea Tehnică „Gheorghe Asachi” din Iaşi \\ Volumul 67 (71), Numărul 3, 2021 \\ Secţia \\ CONSTRUCTII DE MASSINI \\ DOI:10.2478/bipcm-2021-0014 \\ sciendo
}

\title{
STUDY SIMULATION OF UMBILICAL CABLE FOR UNDERWATER VEHICLE
}

\author{
BY
}

\author{
ANDRA-TEODORA NEDELCU ${ }^{1, *}$, CĂTĂLIN FAITĂR ${ }^{2}$, \\ NICOLAE BUZBUCHI ${ }^{2}$ and LIVIU STAN ${ }^{2}$ \\ ${ }^{1}$ Mircea cel Bătrân Naval Academy, \\ Faculty of Navigation and Naval Transport, Constanţa, Romania \\ ${ }^{2}$ Constanţa Maritime University, \\ Faculty of Navigation and Naval Transport, Constanţa, Romania
}

Received: March 29, 2021

Accepted for publication: June 30, 2021

Abstract. This paper presents a series of analyses regarding the tethered umbilical cable in uniform current cable from the composition of the underwater remotely operated vehicle (ROV). The remotely operated vehicle is used in different undersea operation when it is important to control and determine precisely the disturbance forces generated by drag due to currents that act either on the vehicle directly or indirectly on the tether umbilical cable. The dynamics of umbilical cable represent an important part in ocean environment being used for signal and power transmission application. To perform the simulation in Ansys Aqwa, two axis systems are considered. A coordinate system related to the earth, represented by the key in front of which the measurements are made and a second coordinate system related to the vehicle at a set depth relative to the surface of the key. The results obtained from the simulation show us the drag forces that are exerted on the chosen cable for a given length, drag that appear both the seaborne platforms and underwater remotely vehicle contact.

Keywords: ANSYS AQWA; remotely operated vehicle; uniform current.

${ }^{*}$ Corresponding author; e-mail: andra.nedelcu@anmb.ro (C) 2021 Andra - Teodora Nedelcu et al.

This is an open access article licensed under the Creative Commons Attribution-NonCommercialNoDerivatives 4.0 International License (CC BY-NC-ND 4.0). 


\section{Introduction}

The underwater vehicles are nowadays used to realize different and complex technical work such as exploration, inspection and engineering operations in the ocean and deep water industries. The unmanned underwater vehicles (UUVs) are divided into two categories, take into consideration their area of responsibility, shape, autonomy, etc. A higher degree of autonomy, also decrease the operation time for different mission, take into consideration only the dependence of weather conditions or human factors (Schjlberg and Utne, 2015).

The category that are divided the UUVs are: Autonomous Underwater Vehicle (AUVs) and Remotely Operated Vehicles (ROVs). As the name suggest, the vehicle autonomous AUVs have the possibility and ability to operate autonomously without any human intervention. On the other hand, the ROVs typically need human intervention or input help send it using an umbilical cable. The underwater tethered systems are underwater vehicles, tools or other packages attached to a tether (sometimes a cable) and suspended from a vessel or a pier. Generally, the deep-sea operated vehicle systems consist of a support vessel, a winch, umbilical cable and ROV. One of the important properties of all the unmanned underwater vehicle is represented by the hydrodynamic properties. The hydrodynamic properties could affect the performance and the manoeuvrability of the vehicle. This aspect was discuss in many article regarding the design and operation of vehicles.

Generally, most of the study regarding the numerical models for predicting the motion of ROV did not consider important the effect of the umbilical cable and current.

In the paper (Ablow and Schechter, 1983), was proposed an implicit finite difference method to simulate and underwater cable. In paper (Burgess, 1992), was presented several study regarding the current effect on different underwater cable. There are many other studies regarding the effect of the umbilical cable on an underwater flight vehicle.

The ROVs are operated only in weak current this is the reason that most of the design of ROV are realized with the anticurrent capability. In this paper are presented a hydrodynamic ROV design same to an AUV.

The underwater cables and connectors provide system flexibility and ease of service, for undersea equipment - including ROVs. The primary purpose of underwater cables and connectors is to provide a conductive path, without leakage, in a pressure-resistant or pressure tolerant package. Underwater connectors are used to connect the umbilical to a tether management system (TMS) and then from the TMS to the ROV.

The remotely operated vehicle is used in different undersea operation when it is important to control and determine precisely the disturbance forces generated by drag due to currents that act either on the vehicle directly or 
indirectly on the tether umbilical cable. The dynamics of umbilical cable represent an important part in ocean environment being used for signal and power transmission application.

\section{Umbilical Modelling}

In the case of the ROV umbilical system, this is defined by two coordinate systems. One coordinate system is fixed relative to the Earth and the other to the vehicle system. These two systems determine the global and local coordinates of the vehicle respectively. Further, the domain discretization represents a finite number of approximately $\mathrm{N}+1$ local coordinate elements, $\mathrm{N}$ representing the number of elements in which the cable was divided. In other words, each element (node) will have a local coordinate system (Fig. 1).

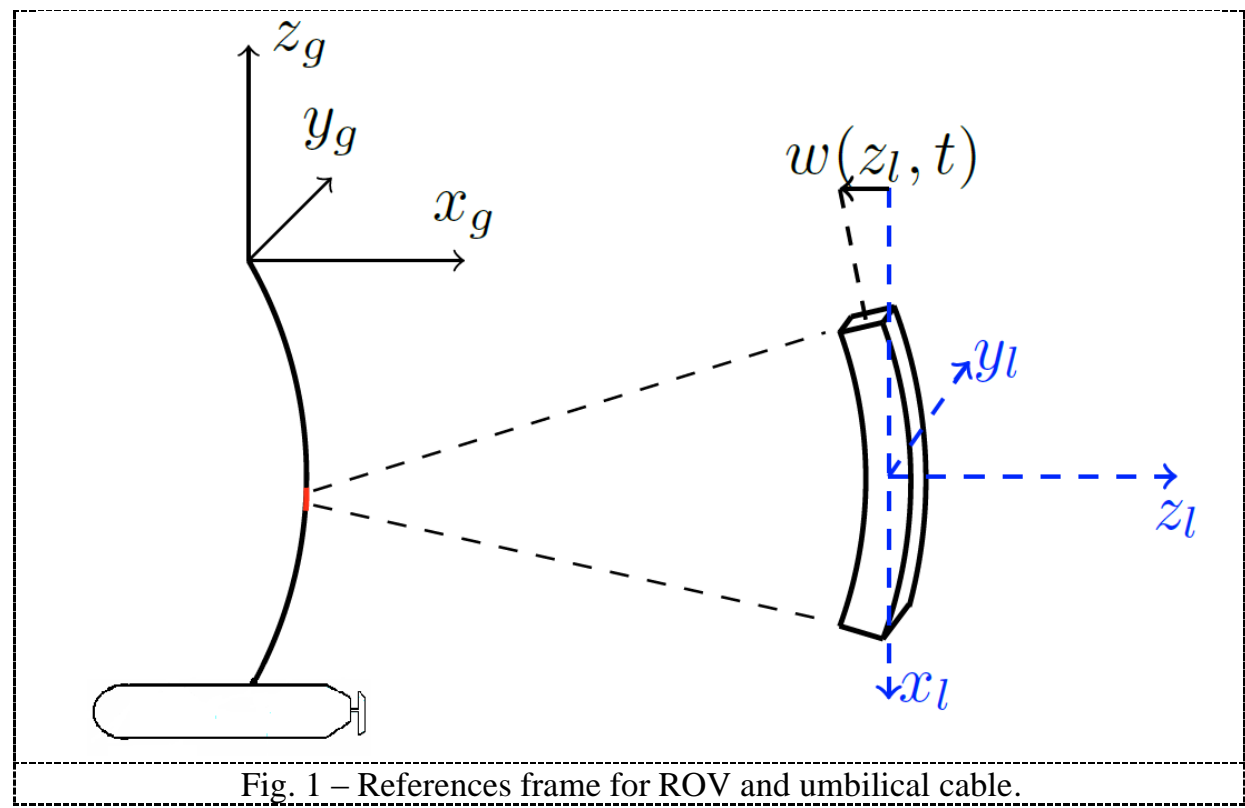

Regarding the governing equations, the cable have three equations (Huang, 1994) take into consideration the 3 dimension space. The longitudinal equation of motion was already described in paper (Weaver et al., 1974) for a beam with uniform cross-section:

$$
S+\frac{\partial S}{\partial x} d x-S-\rho A d x \frac{\partial^{2} u}{\partial t^{2}}=0
$$

In Eq. (1) are presented the following notation: $S$ represent the internal axial stress resultant on the cross-section at a point $\mathrm{x}$ on the beam, $\mathrm{u}$ represent the 
deflection, $\rho$ represent the mass density and A is the area of the cross-section. Using Hookes law the equation can be presented as:

$$
E A \frac{\partial^{2} u}{\partial x^{2}}=\rho A \frac{\partial^{2} u}{\partial t^{2}}
$$

Using the Euler-Bernoulli beam theory, we determinate the transverse equation of motion in y-direction:

$$
\frac{\partial^{2}}{\partial x^{2}} E I_{y} \frac{\partial^{2} v}{\partial x^{2}}+\rho A \frac{\partial^{2} v}{\partial t^{2}}=F_{y}(x)
$$

where $F_{y}(x)$ represents the external load and $I_{y}$ is the second moment of inertia with regards to the y-axis. Similarly the equation in z-direction becomes:

$$
\frac{\partial^{2}}{\partial x^{2}} E I_{z} \frac{\partial^{2} v}{\partial x^{2}}+\rho A \frac{\partial^{2} v}{\partial t^{2}}=F_{Z}(x)
$$

\section{Simulation}

The simulation was realise using the Ansys Aqua Software. First of all, we create the geometry of pier, the urface body and the fixed points. The geometry of pier was then divided intro the submerged pier, ground, upper pier, pier axes, point mass and connection point 1 . The surface body are represented by the surface body, point mass and connection point 2 . The fixed point is represented by fixed point 3 . We consider the water depth of 7 metre, water density $1025 \mathrm{~kg} / \mathrm{m}^{3}$, gravity $9.8 \mathrm{~m} / \mathrm{s}^{2}$ and the water size of domain $177 \mathrm{x} 100 \mathrm{~m}$.

The geometry of pier is presented in Table 1 .

Table 1

The Geometry of Pier

\begin{tabular}{|c|c|}
\hline Name & Pier \\
\hline \hline \multicolumn{2}{|c|}{ Details of Pier } \\
\hline Part Visibility & Vully Defined \\
\hline Activity & Not Suppressed \\
\hline Part Color & 14606046 \\
\hline \multicolumn{2}{|c|}{ Mass Properties from Solver } \\
\hline Total Structural Mass & $99999997952 \mathrm{~kg}$ \\
\hline X Position of COG & $17 \mathrm{~m}$ \\
\hline Y Position of COG & $15.0000009536743 \mathrm{~m}$ \\
\hline Z Position of COG & $-5 \mathrm{~m}$ \\
\hline Moment of Inertia Ixx & $1155999989760 \mathrm{~kg} . \mathrm{m}^{2}$ \\
\hline
\end{tabular}




\begin{tabular}{|c|c|}
\hline Moment of Inertia Ixy & $0.0 \mathrm{~kg} \cdot \mathrm{m}^{2}$ \\
\hline Moment of Inertia Ixz & $0.0 \mathrm{~kg} \cdot \mathrm{m}^{2}$ \\
\hline Moment of Inertia Iyy & $4083200032768 \mathrm{~kg} \cdot \mathrm{m}^{2}$ \\
\hline Moment of Inertia Iyz & 0.0 kg. $\mathrm{m}^{2}$ \\
\hline \begin{tabular}{|l|l} 
Moment of Inertia Izz & \\
\end{tabular} & $4422300073984 \mathrm{~kg} \cdot \mathrm{m}^{2}$ \\
\hline \multicolumn{2}{|c|}{ Advanced Options } \\
\hline Generate Internal Lid & No \\
\hline Current Calculation Position & At Fixed Depth \\
\hline Current Calculation Depth & $7 \mathrm{~m}$ \\
\hline Submerged Structure Detection & Program Controlled \\
\hline Override Calculated GMX & No \\
\hline Override Calculated GMY & No \\
\hline \multicolumn{2}{|c|}{ Fixity Options } \\
\hline Structure Fixity & Structure is Fixed in Place \\
\hline \multicolumn{2}{|c|}{ Force Multiplying Factors } \\
\hline Drag Multiplying Factor & 1 \\
\hline Mass Multiplying Factor & 1 \\
\hline \begin{tabular}{l|l} 
Slam Multiplying Factor & \\
\end{tabular} & 0.0 \\
\hline \multicolumn{2}{|c|}{ Shear Force/Bending Moment Options } \\
\hline Calculate Shear Force/Bending Moment & $\begin{array}{c}\text { Not Permitted for Multiple } \\
\text { Structures }\end{array}$ \\
\hline
\end{tabular}

Also, there are defined the pier point mass in Table 2.

Table 2

The Geometry of Pier Point Mass

\begin{tabular}{||c|c||}
\hline Name & Point Mass \\
\hline State & Fully Defined \\
\hline \multicolumn{2}{|c|}{ Details of Point Mass } \\
\hline Visibility & Visible \\
\hline Activity & Not Suppressed \\
\hline \multicolumn{2}{|c|}{ Mass Properties } \\
\hline Mass Definition & Manual Definition \\
\hline X Position & $17 \mathrm{~m}$ \\
\hline Y Position & $15 \mathrm{~m}$ \\
\hline Z Position & $-5 \mathrm{~m}$ \\
\hline Mass & $100000000000 \mathrm{~kg}$ \\
\hline \multicolumn{2}{|c|}{ Inertia Properties } \\
\hline Kxx & Radius of Gyration \\
\hline Kyy & $3.4 \mathrm{~m}$ \\
\hline Ixz & $6.39 \mathrm{~m}$ \\
\hline Ixy & $6.65 \mathrm{~m}$ \\
\hline
\end{tabular}




\begin{tabular}{||c|c||}
\hline Ixz & $0.0 \mathrm{~kg} \cdot \mathrm{m}^{2}$ \\
\hline Iyy & $4083210000000 \mathrm{~kg} \cdot \mathrm{m}^{2}$ \\
\hline Iyz & $0.0 \mathrm{~kg} \cdot \mathrm{m}^{2}$ \\
\hline Izz & $4422250000000 \mathrm{~kg} \cdot \mathrm{m}^{2}$ \\
\hline
\end{tabular}

The connection point are one attached to structure, and other on the vehicle body. The position coordinate for the one attached to pier are [14.2, 12.5, 3.5].

The surface body geometry are defined in Table 3 .

Table 3

The Geometry of Body

\begin{tabular}{|c|c|}
\hline Name & Surface Body \\
\hline State & Fully Defined \\
\hline \multicolumn{2}{|c|}{ Details of Surface Body } \\
\hline Part Visibility & Visible \\
\hline Activity & Not Suppressed \\
\hline Part Color & 15454648 \\
\hline \multicolumn{2}{|c|}{ Mass Properties from Solver } \\
\hline Total Structural Mass & $768.049072265625 \mathrm{~kg}$ \\
\hline X Position of COG & $2.75000047683716 \mathrm{~m}$ \\
\hline Y Position of COG & $11.9949779510498 \mathrm{~m}$ \\
\hline Z Position of COG & $-2 \mathrm{~m}$ \\
\hline Moment of Inertia Ixx & 88.7864685058594 kg.m² \\
\hline Moment of Inertia Ixy & $0.0 \mathrm{~kg} \cdot \mathrm{m}^{2}$ \\
\hline Moment of Inertia Ixz & $0.0 \mathrm{~kg} \cdot \mathrm{m}^{2}$ \\
\hline Moment of Inertia Iyy & $108.006896972656 \mathrm{~kg} \cdot \mathrm{m}^{2}$ \\
\hline Moment of Inertia Iyz & $0.0 \mathrm{~kg} \cdot \mathrm{m}^{2}$ \\
\hline Moment of Inertia Izz & $116.820259094238 \mathrm{~kg} \cdot \mathrm{m}^{2}$ \\
\hline \multicolumn{2}{|c|}{ Advanced Options } \\
\hline Generate Internal Lid & No \\
\hline Current Calculation Position & At Fixed Depth \\
\hline Current Calculation Depth & $0.0 \mathrm{~m}$ \\
\hline Submerged Structure Detection & Program Controlled \\
\hline Override Calculated GMX & No \\
\hline Override Calculated GMY & No \\
\hline Fixity & \\
\hline
\end{tabular}




\begin{tabular}{||c|c||}
\hline \multicolumn{1}{||c||}{ Structure Fixity } & Structure is Free to Move \\
\hline \multicolumn{2}{|c||}{ Force Multiplying Factors } \\
\hline Drag Multiplying Factor & 1 \\
\hline Mass Multiplying Factor & 1 \\
\hline Slam Multiplying Factor & 0.0 \\
\hline \multicolumn{2}{|c||}{ Shear Force/Bending Moment Options } \\
\hline Calculate Shear Force/Bending Moment & Not Permitted for Multiple \\
& \multicolumn{2}{|c||}{ Structures } \\
\hline
\end{tabular}

The point of mass for surface body is presented in Table 4 .

Table 4

The Point of Mass

\begin{tabular}{|c|c|}
\hline Name & Point Mass \\
\hline State & Fully Defined \\
\hline \multicolumn{2}{|c|}{ Details of Point Mass } \\
\hline Visibility & Visible \\
\hline Activity & Not Suppressed \\
\hline \multicolumn{2}{|c|}{ Mass Properties } \\
\hline Mass Definition & Program Controlled \\
\hline X Position & $2.75000023841858 \mathrm{~m}$ \\
\hline Y Position & $11.9949779510498 \mathrm{~m}$ \\
\hline Z Position & $-2 \mathrm{~m}$ \\
\hline Mass & $768.049059808254 \mathrm{~kg}$ \\
\hline \multicolumn{2}{|c|}{ Inertia Properties } \\
\hline Define Inertia Values By & Radius of Gyration \\
\hline $\mathrm{Kxx}$ & $0.34 \mathrm{~m}$ \\
\hline Kyy & $0.375 \mathrm{~m}$ \\
\hline Kzz & $0.39 \mathrm{~m}$ \\
\hline Ixx & $88.7864713138342 \mathrm{~kg} . \mathrm{m}^{2}$ \\
\hline Ixy & $0.0 \mathrm{~kg} \cdot \mathrm{m}^{2}$ \\
\hline $\mathrm{Ixz}$ & $0.0 \mathrm{~kg} . \mathrm{m}^{2}$ \\
\hline Iyy & $108.006899035536 \mathrm{~kg} . \mathrm{m}^{2}$ \\
\hline Iyz & $0.0 \mathrm{~kg} \cdot \mathrm{m}^{2}$ \\
\hline Izz & $116.820261996835 \mathrm{~kg} . \mathrm{m}^{2}$ \\
\hline
\end{tabular}


The connection point are located on body are $[6,12.5,-1.5] \mathrm{m}$.

The information regarding the cable are presented in Table 5.

Table 5

Cable Caracteristics

\begin{tabular}{|c|c|}
\hline Name & Cable 1 \\
\hline State & Fully Defined \\
\hline \multicolumn{2}{|c|}{ Details of Cable 1} \\
\hline Visibility & Visible \\
\hline Activity & Not Suppressed \\
\hline \multicolumn{2}{|c|}{ General Attributes } \\
\hline Type & Linear \\
\hline Connectivity & Fixed Point to Structure \\
\hline Start Fixed Point & Fixed Point 3 (Fixed) \\
\hline End Connection Point & Connection Point 2 (Surface Body) \\
\hline Initial Attachment Point Separation & $9.60416576283438 \mathrm{~m}$ (Point to Point) \\
\hline \multicolumn{2}{|c|}{ Cable Properties } \\
\hline Stiffness & $1400 \mathrm{~N} / \mathrm{m}$ \\
\hline Unstretched Length & $9.5 \mathrm{~m}$ \\
\hline \multicolumn{2}{|c|}{ Pulley 1} \\
\hline Connection Point & Undefined... \\
\hline
\end{tabular}

In Fig. 2 are presented the design of pier and surface body realized in Ansys Aqua. Here is presented the case where the ROV is in a fixed position.

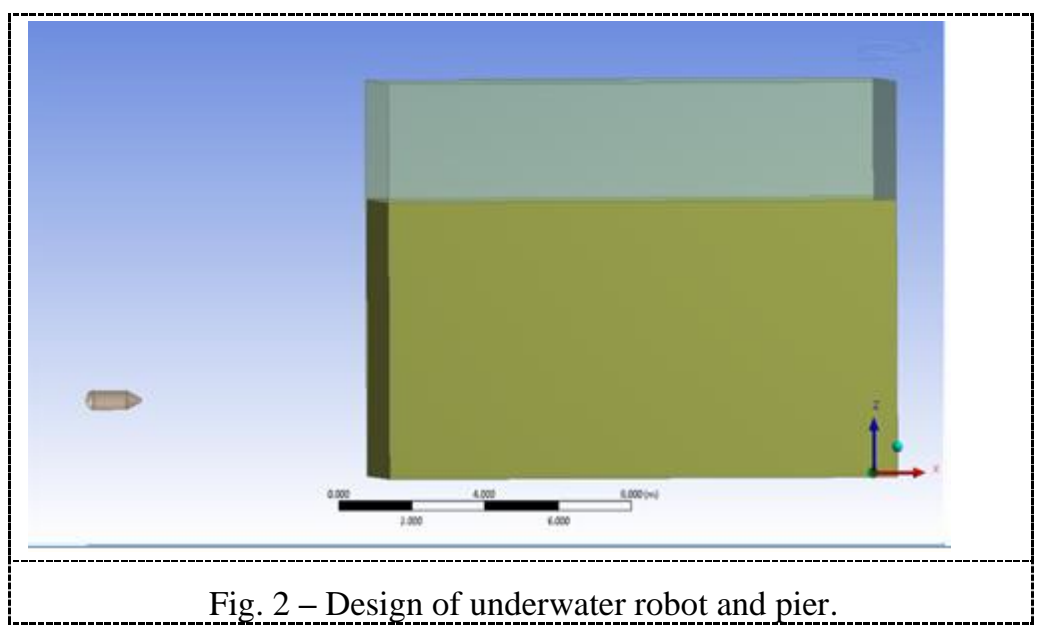


Figure 3 present the mesh of the design.

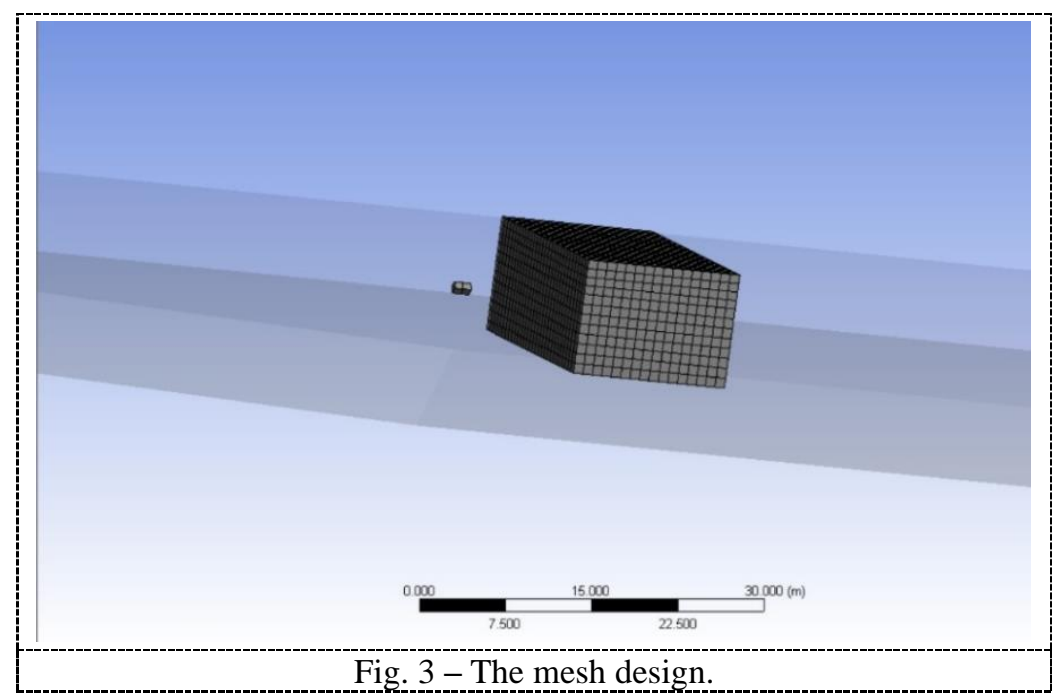

The mesh parameters was set at 0.75 defeaturing tolerance, 1.5 maximum element size and $0.502 \mathrm{~Hz}$ maximum allowed frequency. We confirm a number of 2022 total nodes, 2018 total elements, 822 diffracting nodes and 730 diffracting elements.

Figure 4 present the simulation stade.

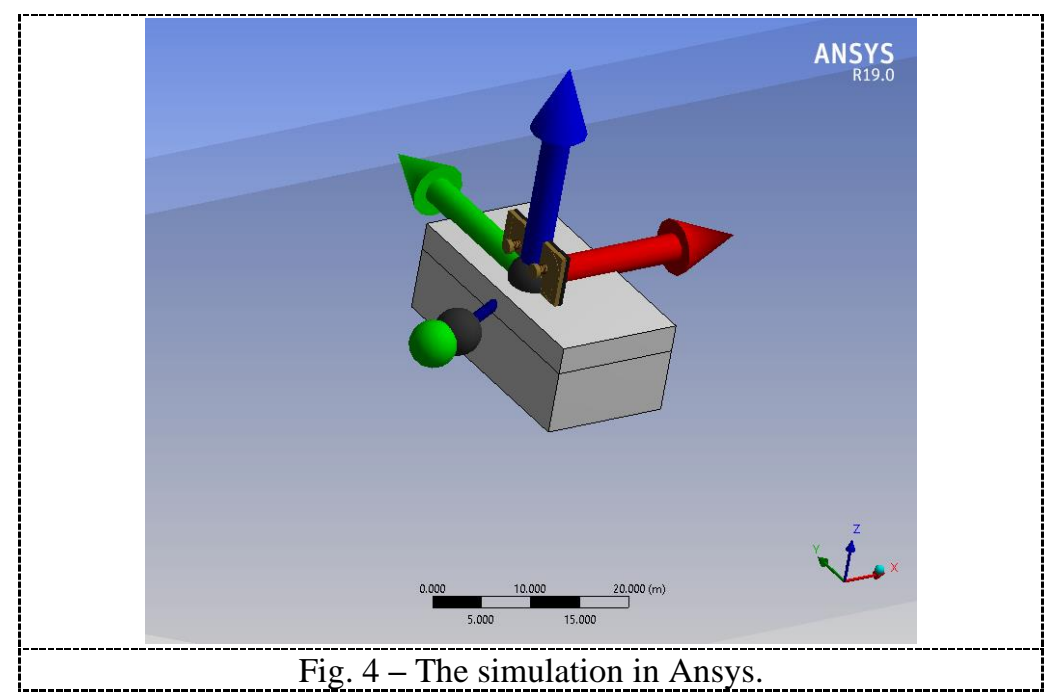

Using the equation for structure body in Line A of RAOs type (Faltinsen, 1990) along the component Global X, frequency of $0.01592 \mathrm{~Hz}$, the 
reference point considered in the center of gravity, and the abscissa position of minimum $60^{\circ}$ to a maximum of $-180^{\circ}$ we perform for distance/rotation vs direction a minimum value of $2.512 \mathrm{~m} / \mathrm{m}$ and a maximum value of $5.288 \mathrm{~m} / \mathrm{m}$ (Fig. 5).

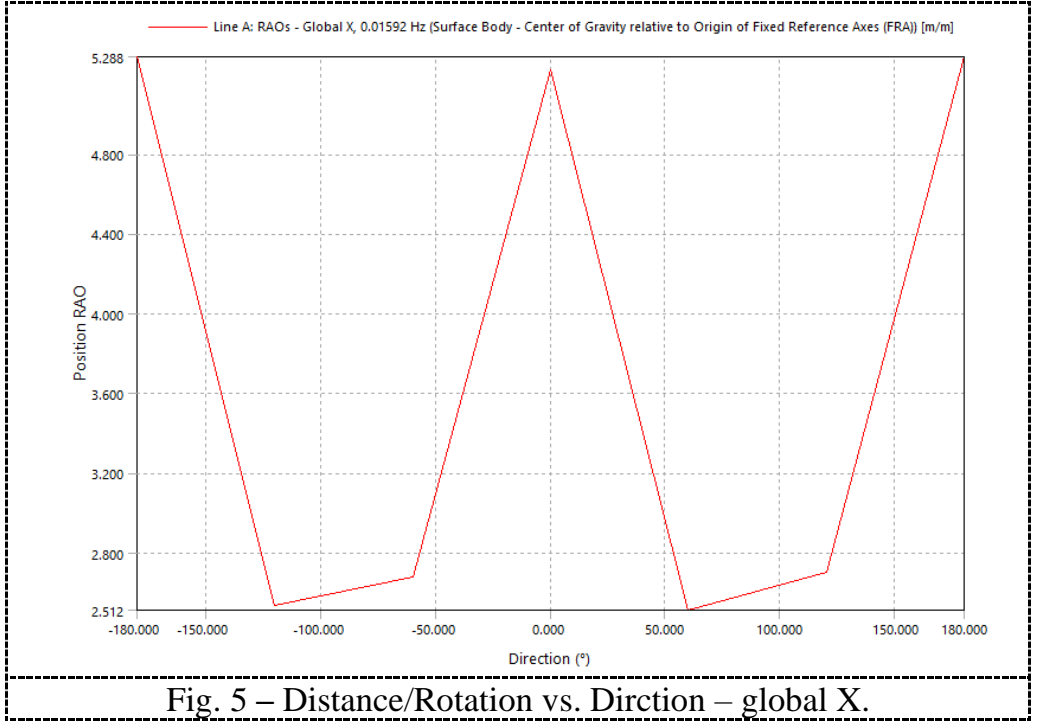

Consider the equation type RAOs, along the component Global RX, the frequency $0.01592 \mathrm{~Hz}$, the abscissa position of minimum of $-120^{\circ}$ to $000^{\circ}$, the minimum value of distance/rotation vs direction is $0.128 \% \mathrm{~m}$ and the maximum value $0.133 \% \mathrm{~m}$ presented in Fig. 6 .

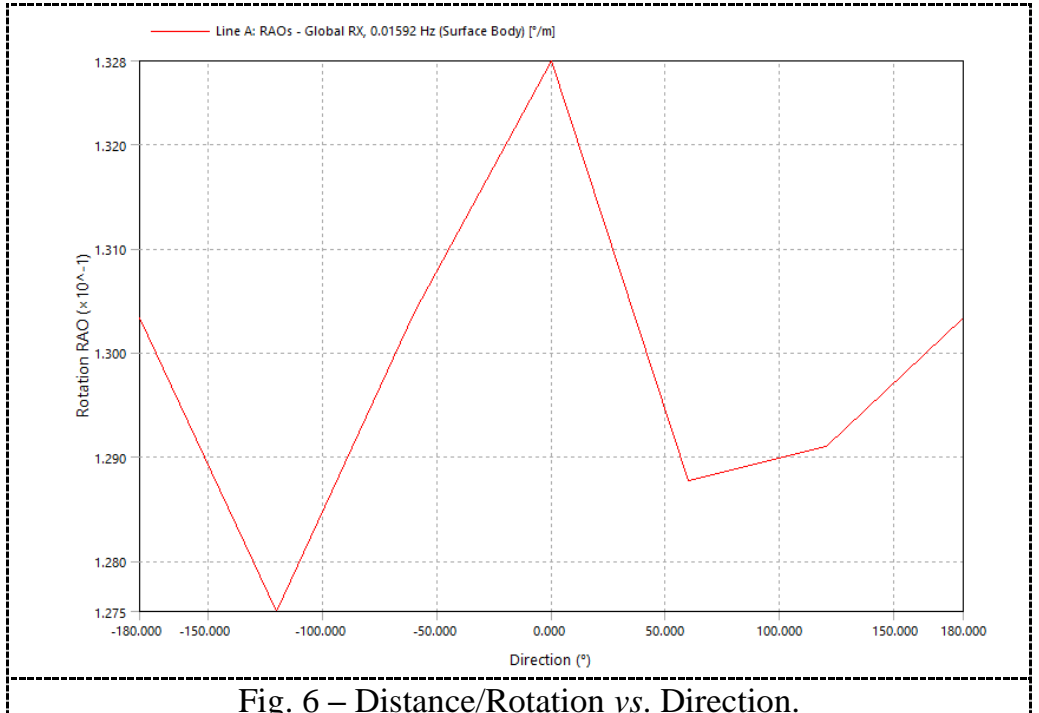

Fig. 6 - Distance/Rotation vs. Direction. 
When we speak about the component along the Global RY, with the abscissa position of minimum situated at $60^{\circ}$ and maximum $180^{\circ}$, we obtained a minimum value of RAOs Distance/Rotation vs Direction of $0.124 \% \mathrm{~m}$ and a maximum value of $0.265 \%$ according to Fig. 7 .

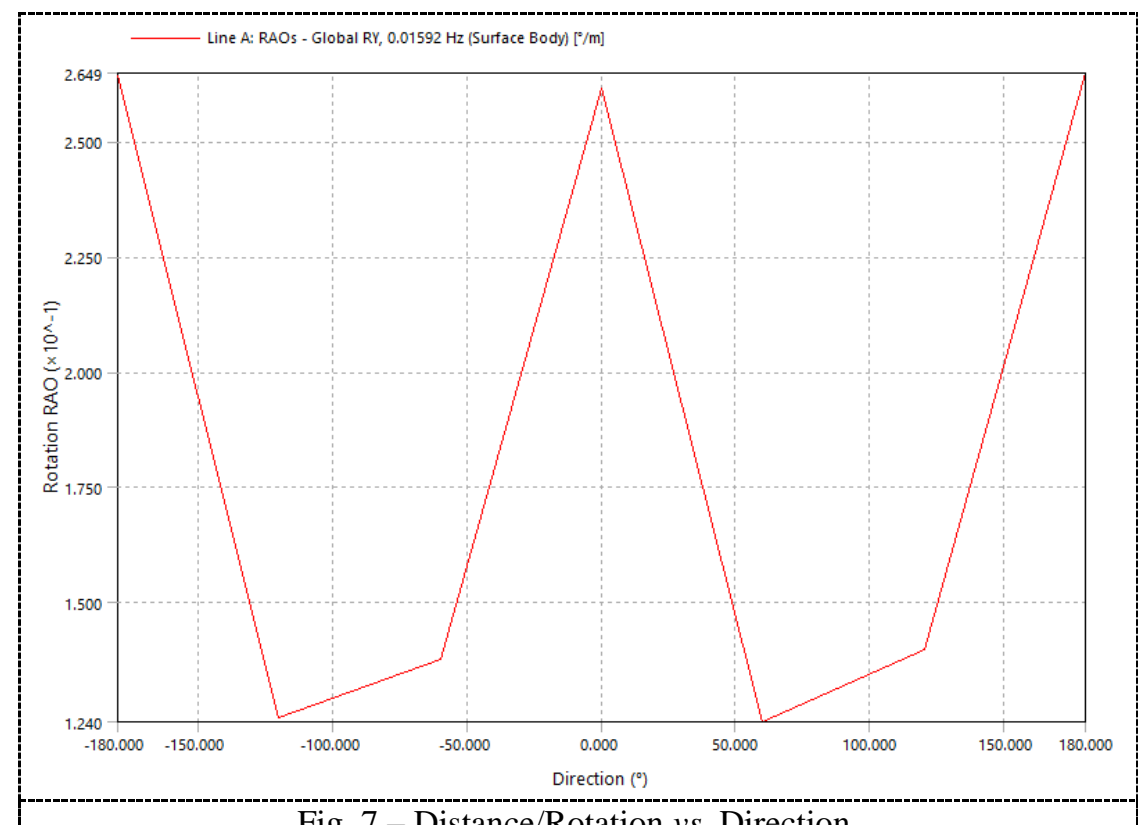

Fig. 7 - Distance/Rotation $v s$. Direction

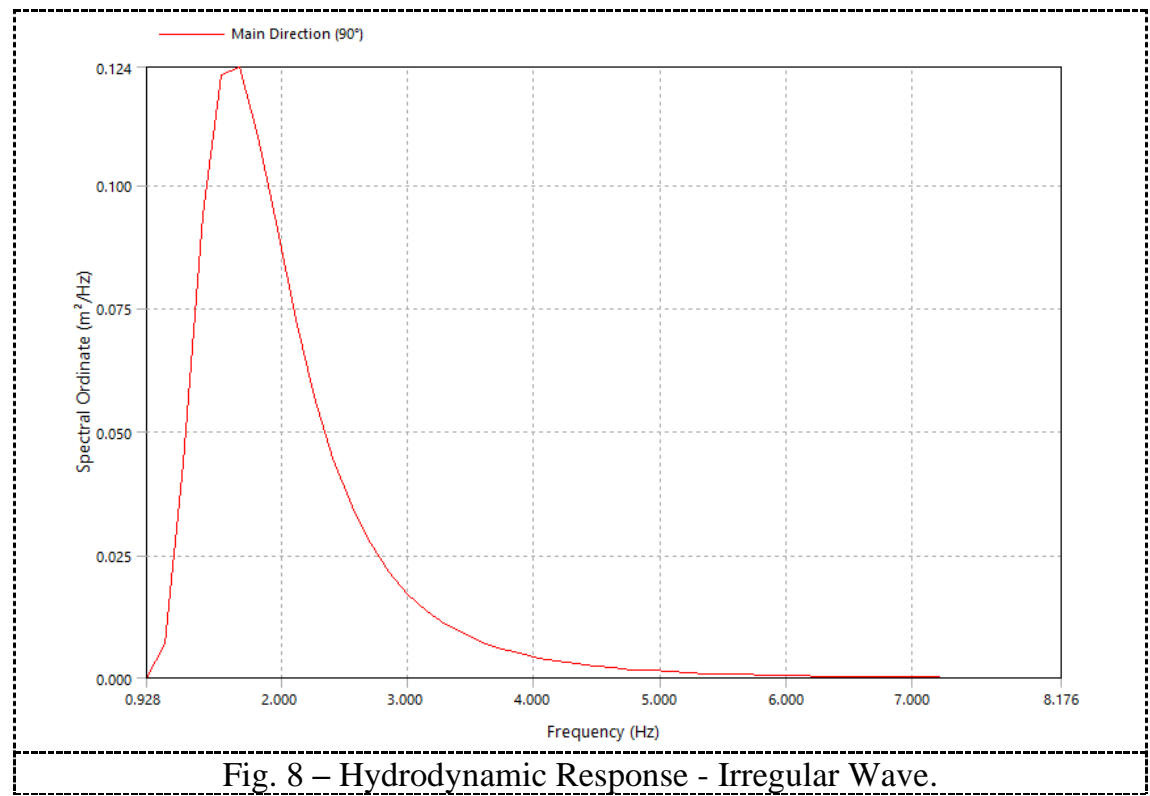


Take into consideration some details of irregular wave spectrum defined as JONSWAP (Hs) (Pierson et al., 1964), from $90^{\circ}$ direction of spectrum, with a start frequency of $0.928 \mathrm{~Hz}$ and a finish frequency of $8.17616 \mathrm{~Hz}$, the data obtained are presented in Fig. 8 and Table 6.

Table 6

Hydrodynamic Response -Irregular Wave

\begin{tabular}{|c|c|}
\hline Frequency $(\mathrm{Hz})$ & Spectral Ordinate $\left(\mathrm{m}^{2} / \mathrm{Hz}\right)$ \\
\hline Direction $\left(^{\circ}\right) \rightarrow$ & 90 \\
\hline Sub-Weight $\rightarrow$ & 1 \\
\hline 0.928 & $1.06815 \mathrm{e}-4$ \\
\hline 1.07592 & $7.07437 \mathrm{e}-3$ \\
\hline 1.22384 & 0.04355 \\
\hline 1.37176 & 0.09384 \\
\hline 1.51969 & 0.12238 \\
\hline 1.66761 & 0.12388 \\
\hline 1.81553 & 0.10991 \\
\hline 1.96345 & 0.091 \\
\hline 2.11137 & 0.07272 \\
\hline 2.25929 & 0.05716 \\
\hline 2.40722 & 0.04467 \\
\hline 2.55514 & 0.03491 \\
\hline 2.70306 & 0.02739 \\
\hline 2.85098 & 0.02161 \\
\hline 2.9989 & 0.01717 \\
\hline 3.14682 & 0.01374 \\
\hline 3.29475 & 0.01107 \\
\hline 3.44267 & $8.98896 \mathrm{e}-3$ \\
\hline 3.59059 & $7.34986 \mathrm{e}-3$ \\
\hline 3.73851 & $6.05071 \mathrm{e}-3$ \\
\hline 3.88643 & $5.01375 \mathrm{e}-3$ \\
\hline 4.03435 & $4.18035 \mathrm{e}-3$ \\
\hline 4.18228 & $3.50607 \mathrm{e}-3$ \\
\hline 4.3302 & $2.95703 \mathrm{e}-3$ \\
\hline 4.47812 & $2.50719 \mathrm{e}-3$ \\
\hline 4.62604 & $2.13647 \mathrm{e}-3$ \\
\hline 4.77396 & $1.82923 \mathrm{e}-3$ \\
\hline 4.92188 & $1.57323 \mathrm{e}-3$ \\
\hline 5.06981 & $1.35885 \mathrm{e}-3$ \\
\hline
\end{tabular}




\begin{tabular}{||c|c||}
\hline 5.21773 & $1.17843 \mathrm{e}-3$ \\
\hline 5.36565 & $1.02591 \mathrm{e}-3$ \\
\hline 5.51357 & $8.96392 \mathrm{e}-4$ \\
\hline 5.66149 & $7.8595 \mathrm{e}-4$ \\
\hline 5.80941 & $6.91397 \mathrm{e}-4$ \\
\hline 5.95734 & $6.10137 \mathrm{e}-4$ \\
\hline 6.10526 & $5.40048 \mathrm{e}-4$ \\
\hline 6.25318 & $4.79382 \mathrm{e}-4$ \\
\hline 6.4011 & $4.26698 \mathrm{e}-4$ \\
\hline 6.54902 & $3.80799 \mathrm{e}-4$ \\
\hline 6.69694 & $3.40691 \mathrm{e}-4$ \\
\hline 6.84486 & $3.0554 \mathrm{e}-4$ \\
\hline 6.99279 & $2.74646 \mathrm{e}-4$ \\
\hline 7.14071 & $2.47422 \mathrm{e}-4$ \\
\hline 7.28863 & $2.23369 \mathrm{e}-4$ \\
\hline 7.43655 & $2.02065 \mathrm{e}-4$ \\
\hline 7.58447 & $1.83151 \mathrm{e}-4$ \\
\hline 7.73239 & $1.66321 \mathrm{e}-4$ \\
\hline 7.88032 & $1.51311 \mathrm{e}-4$ \\
\hline 8.02824 & $1.37897 \mathrm{e}-4$ \\
\hline 8.17616 & $1.25884 \mathrm{e}-4$ \\
\hline
\end{tabular}

The effect of the current force on the umbilical cable will affect ROV motions, because the umbilical cable is connected to the ROV body. In other words, both umbilical cable and ocean current indeed affect the motion behaviors of the ROV.

\section{Conclusion}

In the paper, was presented in the first part the Euler-Bernoulli equation beam to model the force of an ROV. This model is used most of the time to simulate the dynamics of an umbilical cable, exactly yhe rigid body forces and the hydrodynamic forces. Also, using software specialized, was realise the design of an underwater vehicle towered using a umbilical cable from the surface. The model can be easier extended included additional effects, for example, the ship motion in case of a tethered vehicle from the board of a ship. In the paper was presented the case where the ROV is in a fixed position. From the last simulation, it is show that the dynamics of an umbilical cable depend of current direction and velocity. The influence of current is simulated using Ansys software. Both umbilical cable and ocean current indeed affect the motion behaviors of the ROV, and this makes if necessary to paid careful attention. 


\section{REFERENCES}

Ablow O.M., Schechter S., Numerical Simulation of Undersea Cable Dynamics, Ocean Engineering, 10, 6, 443-457 (1983).

Burgess J.J., Equations of Motion of a Submerged Cable with Bending Stiffness, Offshore Marine and Arctic Engineering, I-A, 283-289 (1992).

Faltinsen O.M., Sea Loads on Ships and Offshore Structures, Cambridge University Press, ISBN 0-521-45870-6 (1990).

Huang S., Dynamic Analysis of Three-Dimensional Marine Cables, Ocean Engineering, 21, 6 (1994).

Pierson Willard J.Jr., Moskowitz Lionel, A Proposed Spectral Form for Fully Developed Wind Seas Based on the Similarity Theory of S. A. Kitaigorodskii, Journal of Geophysical Research, 69, 5181-5190 (1964).

Schjlberg I., Utne I.B., Towards Autonomy in ROV Operations, IFAC-PapersOnLine 2015, 48, 2, 183-188 (2015).

Weaver Jr.W., Timoshenko S.P., Young D., Vibration Problems in Engineering, John Wiley \& Sons Inc. (1974).

\section{STUDIUL PRIVIND SIMULAREA CABLULUI OMBILICAL AL VEHICULELOR SUBACVATICE}

\section{(Rezumat)}

Această lucrare prezintă o serie de analize privind influența curentului subacvatic asupra cablului ombilical al vehiculelor subacvatice telecomandante de la distanţă (ROV). Vehiculul acționat de la distanţă este utilizat în diferite operațiuni subacvatice atunci când este important să se controleze și să se determine cu precizie forțele de perturbare generate de forța de înaintare influențată de parametri meteorologici care acționează fie direct asupra vehiculului, fie asupra cablului ombilical. Cablul ombilical reprezintă o parte importantă din complexul vehiculului și are funcții importante, dintre care amintim de transmiterea semnalului și a puterii pentru manevrarea vehiculului. Pentru a efectua simularea în Ansys Aqwa, sunt luate în considerare sistemele cu două axe. Rezultatele obținute în urma simulării ne arată forțele de tracțiune care sunt exercitate pe o anuită lungime a cablului ales. 